\section{Rakkaudella rakkautta tutkimassa}

Eva Maria Korsisaari Tule rakkaani! Naisen ja miehen välisestä etiikasta kirjallisuuden rakkauskuvauksissa. Helsinki: Kustannusosakeyhtiö Teos 2006. 470 s.

Eva Maria Korsisaaren väitöskirjan nimi Tule rakkaani! Naisen ja miehen välisestä etiikasta kirjallisuuden rakkauskuvauksissa kertoo tärkeimmän teoksen sisällöstä. Haaste on suuri: otsikko kattaa mahdollisesti koko maailmankirjallisuuden heteroseksuaaliset rakkauskuvaukset! Käytännössä Korsisaari on subjektiivista valintaa käyttäen valinnut muutaman kirjailijan tai teoksen edustamaan erilaisia rakkaudesta kirjoittamisen malleja kautta vuosisatojen, Shelleystä Barbara Cartlandiin ja 1100-luvun trubaduurirunoilijoista ranskalaiseen nykyrunoilija Guilleviciin. Rakkauden varsinaisia klassikkoja edustavat Platonin Pidot ja Raamatun "Laulujen laulu". Tutkimuskorpuksen rajaustapa sopii Korsisaaren työn metodiin, jossa objektiivisen tutkimuksen sijasta tavoitellaan toisenlaista tutkimuksen tapaa ja jossa tutkijan omat tuntemuksetkin voivat olla osa tutkimusta. Perinteiseen tieteelliseen tekstiin tottunutta väitöstutkimuksen ratkaisut voivat kiusata, toista taas ne voivat erityisesti miellyttää.

Lähes jokainen kirjallisuudentutkija, joka on opiskellut tai tehnyt tutkimusta 1990-luvulla, tuntee ainakin pinnallisesti jo 1970-luvulta lähteneen erityisesti Ranskaan sijoittuneen paradigman, jossa tutkimuksen kieltä on pyritty uudistamaan. Objektiivisuus, jonka passiivissa puhuva yksiselitteisyyteen pyrkivä kieli tuotti, nähtiin valheeksi. Naistutkijat ovat tuominneet objektivoivan kielen ensi sijassa miesten kirjoittamisen tavaksi, vaikka yksi tällaisen kielen kovimmista kriitikoista on mies, Roland Barthes. Hän on myös kirjoittanut rakkaudesta ja subjektiivisten tunteiden yhteydestä lukemiseen. Tämä on keskipisteenä Korsisaarenkin väitöskirjassa. Tule rakkaani! -teoksessa Barthes esiintyy kuitenkin vain mainintana, koska Korsisaari keskittyy sukupuolineutraalin rakastamisen sijasta pohtimaan rakkautta sukupuolieron kautta, naisen ja miehen välistä rakkautta. Toisaalta hän etsii tutkimistaan rakkauskuvauksista erilaista kirjoittamisen tapaa, feminiinistä kirjoitusta tai naisen kieltä. Korsisaaren innoittajina ovat Hélène Cixous ja ennen kaikkea Luce Irigaray. Vaikka ranskalaisten ajatuksia on opiskeltu jo kauan, on Korsisaaren väitöskirja ensimmäinen suomalainen kirjallisuustieteen väitöskirja, jossa pyritään soveltamaan uudenlaista tutkimuskirjoittamisen ja tutkimuksen tekemisen tapaa.

Luce Irigarayn varhaisemmissa kirjoituksissa näkemys toisenlaisesta, feminiinisestä kielestä tarkoittaa monitulkintaista, runollista ja vaikeaselkoista kirjoittamista, samankaltaista kuin Cixous'ltakin tavataan. Tutkijat siis itse kirjoittivat monitulkintaisesti ja varoen väittämästä mitään suoraan. Heidän arvostamiensa ja tutkimiensa avantgarde-kirjailijoiden kieli oli paljolti samanlaista. Korsisaari eroaa 
esikuvastaan Irigaraysta siinä mielessä, että hänen esimerkkikirjailijoissaan uudenlaista kirjoittamisen tapaa edustavat kirjailijat, joiden runoutta voi ymmärtää kuka tahansa kirjallisuuden ystävä. Esimerkiksi Guillevic, jonka eroottisesta runoudesta Korsisaari antaa viljalti näytteitä, kuulostaa Tommy Tabermannin sukulaissielulta. Samoin Korsisaaren oma kirjoitus on selkeää. Sen ero tavalliseen tutkimuskirjoittamiseen näkyy esseistisyydessä ja monissa kysymysmerkeissä, tietoisessa pyrkimyksessä kauniiseen tyyliin ja ankaran tieteellisen argumentoinnin välttämisessä. Lähdeviitteet ja pidemmät pohdinnat esimerkiksi Irigarayn projektin tiimoilta Korsisaari on jättänyt loppuviitteisiin.

Analyysinsa apuna Korsisaari käyttää Irigarayn käsitteitä "saman rakkaus", "saman toisen rakkaus" ja "toisen rakkaus". Erityisesti ensimmäinen näistä on Irigarayn ja tätä seuraavan Korsisaaren mielestä eettisesti ongelmallinen käsite. Saman rakkaudella Irigaray tarkoittaa rakastetun näkemisenä itsensä kaltaisena, minkä seurauksena toisen perimmäinen vieraus katoaa ja toinen sulautetaan itseen. Saman rakkautta on myös toisen rakastaminen omien tarpeiden täyttämisen takia. Saman toisen rakkaudella taas tarkoitetaan samaan sukupuoleen kohdistuvaa rakkautta, jossa miesten kohdalla aistimellinen rakkaus itsessään on väistynyt muiden tavoitteiden tieltä: tärkeintä on miehen itseensä kohdistuva rakkaus ja suhteiden rakentaminen muihin miehiin. Naisten kesken tällaista rakastamista ei ole Iriga- rayn mukaan vielä edes kehitetty. Toisen rakkaus sen sijaan on rakastamista tavalla, jossa toisen erilaisuus itsestä säilyy. Toista lähestytään kunnioittavan ihmettelyn kautta ja kumpikin rakastamisen osapuolista pysyy omana subjektinaan.

Ensimmäisessä analyysiluvussaan Korsisaari tulkitsee niin Platonin Pitojen kuin Shelleyn rakkausrunouden, Emily Brontën Humisevan harjun sekä Barbara Cartlandin viihderomaanien kuvaavan "saman rakkautta", jossa rakastetulla ei oikeastaan ole omaa merkitystä, vain käyttöarvo toisen subjektiuden täydentäjänä. Positiivisempaa rakkauden kuvaamisen mallia taas edustavat loput Korsisaaren analyyseista: naispuolisten trubaduurien runot, Raamatun Laulujen Laulu ja Guillevicin runous. Naistrubaduurien runoista Korsisaari jäljittää feminiinistä kirjoitusta, joka eroaa miestrubaduurien vastaavien runojen tyylistä. Korsisaaren mukaan miehet ihailevat kirjoituksissaan ideaalia, jolla erityisesti naisten kirjoitusten valossa ei ole mitään tekemistä todellisuuden kanssa. Lopulta kyseessä ei ole toisen rakastaminen vaan enemmän joko saman rakastaminen tai toisen saman rakastaminen, koska osaksi miesten trubaduurirunous on heidän oman maskuliinisuutensa rakentamista niin itsen kuin toisten miesten silmissä runouden kautta. Naiset taas haluavat kohdata avoimen ruumiillisesti rakastamansa miehen ja samalla uudistaa trubaduurirunouden konventioita omalla feminiinisellä tavallaan.

Korsisaaren kuvaama varhainen runous on kiinnostavaa, varsinkin kun naistru- 
baduurien runoutta ei ole ollut suomeksi saatavilla. Naisten runot kuulostavat yllättävän moderneilta, ja mielenkiintoista on myös ero, jonka Korsisaari havaitsee miesten ja naisten kirjoittaman runouden välillä. Mutta kun Korsisaari kuvaa sitä, mitä feminiininen kirjoitus voisi olla, minua mietityttää jälleen kerran väitteiden essentialistisuus, yleistävyys ja idealistisuus. Irigarayta tukevat tutkijat, Korsisaari mukaan lukien, toki selittävät syytteet essentialistisuudesta parhain päin vedoten $\mathrm{mm}$. Irigarayn perusajatukseen, ettei naisen kieltä voi vielä edes suoraan kuvata. Kuten Korsisaari toteaa, kirjallisuudentutkijan on kuitenkin jotenkin pystyttävä soveltamaan esitettyjä käsitteitä ja silloin on esitettävä joitakin selviä väitteitä naisen kielestä. Hänen perustelunsa, että naisen kieli on aina tilanteista ja muuttuvaa tapauksesta toiseen, kuulostaa järkevältä. Korsisaaren esimerkit kuulostavat uskottavilta, mutta vielä haluaisin varmistua, kuvaavatko Korsisaaren esittelemät runot tosiaan kaikkea naisten kirjoittamaa trubaduurirunoutta vai ovatko kuitenkin kyseessä erityistapaukset. Ja mitkä muut tekijät kuin abstrakti feminiinisyys selittäisivät eroja?

"Laulujen laulu" taas on Korsisaaren mukaan hyvä esimerkki dialogisesta rakkauden kirjoittamisesta; toinen kohdataan ilman toisen palauttamista itseen. Guillevic kuvaa Irigaraylle ominaisesti rakastavaisten välistä rakastavaa kohtaamista, kosketuksia, hyväilyjä, vastavuoroisia vierailuja toisen sisätiloissa ja taas palaamista omien rajojen sisälle. Guillevicin analyysi on väitöskirjan viimeinen varsinainen luku eikä siinä ehditä kovin syvälle. Sanatasolla Guillevicin runous todella tuntuu lähes toistavan Irigarayn näkemyksiä rakkaudesta naisen ja miehen välillä.

Korsisaaren mukaan hänen pyrkimyksensä on "rakkaudella tutkiminen" eli tutkimuskohteen lähestyminen Irigarayn rakastavan kohtaamisen välinein: hellyydellä, kunnioittavasti tunnustellen, pyrkimättä sulauttamaan toista itseensä. Hän itse sanoo väitöskirjaansa kuvaavan paremmin sanaparin "kysymysten kirja". Lukuisista kysymysmuotoisista lauseista huolimatta itselleni Korsisaaren tutkimuksesta hahmottui selviä väitteitä. Minulle tuli mieleen lukuisia kysymyksiä, jotka johtuivat juuri siitä, että tunsin tutkijan asettaneen kirjailijat tiukasti tietynlaisen rakkauskuvauksen kannattajaksi. Eivätkö esimerkiksi Shelleyn toistuvat rakastettuun liittyvät kysymykset voisi olla ihmetyksellä lähestymistä, toisen vierauden kummastelua? Eikö tietylle ajalle sopivaa idealisoivaa rakkauskuvastoa ja toisaalta sitä rikkovaa vierauden kuvausta voi esiintyä yhtäaikaisesti? Entä voisiko "Laulujen laulun" muodostuminen sekä miehen että naisen lausumista repliikeistä kuvata yhtä hyvin yhteensulautumista kuin toisen erillisyyttä kunnioittavaa dialogia? Mitä merkitystä taas on aivan muiden ihmisten äänillä "Laulujen laulussa"? Ja pitääkö toisen kautta täydellistymiseen pyrkivän rakkauden olla aina negatiivista ja toisen haltuun ottavaa?

Osaksi Korsisaaren tutkimus on tehty naistutkimukseen, johon se aiheensa puolesta hyvin sopii. Mahdollisesti myös Tule 
rakkaani! -teoksen kirjoittamisen tapa on nähty sopivammaksi naistutkimukseen kuin kirjallisuustieteeseen, vaikka kirjallisuustieteessä jos missä pitäisi suvaita myös tutkimuskirjoittamiseen liittyviä kokeiluja. Toisaalta yleiskustantajan leivissä julkaiseminen tuo Korsisaaren yleisöksi myös akatemioiden ulkopuolisen yleisön ja hänen lukijaystävällinen tyylinsä puhuttelee ketä tahansa aiheesta kiinnostunutta. Tästä lienee aiheutunut se, että erityisesti ensimmäisessä luvussa Korsisaari on voinut kirjoittaa pinnallisestikin tutkimuksensa taustoista.

On hienoa, että joku uskaltaa ottaa osaa tutkimuskirjoittamisen uudistamiseen suuren ja tärkeän projektin, väitöskirjan, puitteissa. Irigarayn aineettoman filosofian soveltaminen konkreettisiin teksteihin ei ole helppoa, ei myöskään feminiiniseksi kutsutun kielen etsiminen.

\section{Päivi Koivisto}


Kansallisrunoilija, pedofiili ja homoseksuaali?

Panu Rajala: Runoilijan sydän. J. H. Erkon täyttymätön elämä. Helsinki: Otava, 2006. 349 s.

Viime vuonna vietettiin kirjailija J. H. Erkon (1849-1906) kuoleman satavuotismuistovuotta. Juhlavuoden kunniaksi ilmestyi myös Panu Rajalan Runoilijan sydän -elämäkertateos Juhana Heikki (Johan Henrik) Erkosta. Muihin keskeisiin viime vuosisadan vaihteen kirjailijoihin verrattuna Erkko on nykyisin varsin tuntematon. Epookkia on totuttu lukemaan realismin aikana, eikä Erkko ollut realisti. Rajalan loppusanojen mukaan Erkko kuitenkin oli "kiistatta johtava ja näkyvin kirjailijamme kolmenkin vuosikymmenen ajan 1800-luvun lopussa”. Lukija odottaakin Rajalan teoksessaan tuovan Erkon tuotannon omaleimaisuuden merkityksen esiin ajan hallitsevien realistien, Minna Canthin ja Juhani Ahon, varjosta. Tähän haasteeseen Rajala ei lähde vastaamaan, vaan keskittyy tunnelmoimaan Erkon surkuhupaisalla rakkauselämällä ja esittelee tuotantoa vain siinä mär̈in, kuin se kuvittaa näitä tunnelmia. Rajalan tietokirjana markkinoitua teosta ei voida pitää täysivoimaisena dokumentaarisena elämäkertana, vaan enemminkin kuviteltujen tunnelmien ja tunteiden varaan rakentuvana romaanina.

Rajala on valinnut elämäkertaromaaninsa kertojaksi Erkon aikalaisen, Fanny Davidsonin (myöh. Sartto, 1877-1962).
Teos alkaa laajalla jaksolla, jossa Fanny kertoo, kuinka viittäkymmentä lähestyvä herrasmiesrunoilija tulee vuokralaiseksi hänen isänsä taloon ja rakastuu häneen. Naimakauppaa ei kuitenkaan synny, kun Erkko paljastaa Fannyn isälle radikaalit mielipiteensä työväen asemasta. Ajattelematon idealismi pudottaa kansallisrunoilijan Fannyn perheen hänelle osoittamalta korokkeelta. Fanny ei kuitenkaan saa runoilijaa mielestään, vaan päättää myöhemmin kirjoittaa maisterintutkielmansa tämän elämästä ja runoudesta. Kun professori Estlander suhtautuu kielteisesti tutkielman aiheeseen, Fanny päättää joka tapauksessa kirjoittaa vanhasta kosijastaan, ja enemmänkin kuin tutkielman, oikean kirjan.

Tämän kehyskertomuksen jälkeen Fanny alkaa kertoa Erkosta elämänkerturin ottein. Lapsuuden vuosia tarkastellaan lineaarisesti edeten ja koulutien mutkat selvitetään tarkasti. Varsinaiseen punaiseen lankaansa teos pääsee kuitenkin kiinni vasta Erkon kehityttyä nuoreksi mieheksi, joka toistamiseen todetaan komeaksi ja naisia viehättäväksi. Tästä eteenpäin Erkon elämän kuvataan etenevän ihastuksesta toiseen. Ajankohdan määrityksestä tulee toissijaista, Erkon vanheneminen laitetaan merkille vain siitä, että hänen ihastuksensa yhä nuorenevat. Elämäkerturin kuivakka raportoiva ääni muuttuu kaikkialle tunkeutuvaksi, intiimejä yksityiskohtia raportoivaksi kaikkitietävän kertojan paljastuskertomukseksi, jonka lomaan limittyy Erkon omia fiktiivisiä tilityksiä ja muiden pai- 
kalla olleiden todistuksia, joita Fanny on aineistokseen "kerännyt".

Kosintojen sarja synnyttää tragikoomisen kuvan yritteliäästä romantikosta, joka kerta toisensa jälkeen kompastuu omaan idealismiinsa ja kevytmielisyyteensä. Ellei nainen anna rukkasia tai hänen perheensä kiellä Erkkoa, pakenee herrasmiesrunoilija itse vähin äänin paikalta - esimerkiksi havaittuaan kosintansa jälkeen, että morsiamella on vastenmielinen ääni. Teoksen alaotsikossa implikoitu elämän täyte, joka Erkolta jäi saavuttamatta, oli siis avioliitto ja perhe-elämä. Tämä puute nousee Rajalan teoksessa Erkon kirjallisia tai yhteiskunnallisia saavutuksia merkityksellisemmäksi. Lukijalle mainitaan kyllä useaan kertaan, että Erkko oli luonteeltaan tulinen ja asioihin tarttuva, mutta saamattoman kosijan potretti on tätä rehevämpi ja painokkaampi. Näin kaikki muut Erkon tekemiset jäävät naisretkien varjoon.

Jopa Euroopan matka, jolle Erkko lähti tutustumaan realistiseen suuntaukseen erityisesti draamassa, kuvataan vain sarjana uusia ihastuksia ja seikkailuja. Suhde Juhani Ahoon ja muihin nuorsuomalaisen piirin miesjäseniin jää etäiseksi. Sen sijaan Minna Canthin merkitystä painotetaan, koska Erkon kuvaillaan välttelevän voimanaista. Tosiasiassa Canthin suhde J. H. Erkkoon oli etäinen, muutamissa tälle kirjoittamissaan kirjeissä hän teitittelee tätä. Erkon todellisen elämäkerran kannalta merkittävämpää olisi ollut piirtää esiin hänen suhdettaan realisti-Ahoon ja muihin maailmaa matkaaviin nuorsuomalaisiin, jotka olivat hänel- le henkilökohtaisesti paljon läheisempiä. Naissuhteita kiinnostavampia kysymyksiä olisivat elämäkerrassa kenties olleet myös suomalaismielisen Erkon suhde vaikkapa kosmopoliittisuuteen ja Pariisin tautiin, Euroopan paheellisuuden ytimestä leviävään naturalismiin. Ylipäätään Rajalan teos käsittelee Erkon kirjallista tuotantoa varsin vähän. Vain näytelmät Tietäjä (1887) ja Aino (1893) saavat tekstissä enemmän tilaa, runoista esille tuodaan lähinnä ne, joita Erkko on kulloisestakin ihastuksestaan riimitellyt.

Loppusanoissaan Rajala itse kertoo valinneensa kertojaksi Fanny Davidsonin, koska hänen kauttaan Erkkoa voitiin tarkastella läheltä, naisen näkökulmasta. Kertoja eläytyy Erkon kuviteltuihin tunteisiin ja arvostaa naisia lähinnä näiden kosintakelpoisuuden mukaan. Saamattomaksi kosijaksi mainittu Erkko on miehenä valitsijan roolissa, naiset vain odottavat ja alistuvat. Usein avioliitto kompastuu isän, ei tytön itsensä, kieltoon. Naiskertojan sympatia on epäonnisen Erkon puolella. Vaikka naimatapa oli ajalle ominainen ja naisen rooli nähtiin passiivisena mieheen nähden, minkäänlaista kritiikkiä tai emansipaatiota naiskertojan kertomuksesta ei löydy. Kaikki Erkon kohtaamat naiset arvioidaan ulkonäön perusteella. Jopa veljen morsian Hilda Asp saa lausunnon "ei kaunis, älykäs kyllä”. Kuinka uskottava tällainen naiskuva on naimattoman, yhteiskunnallisesti aktiivisen naisen kertomaksi?

Rajalan kertojaksi muotoilema Fanny onkin fiktiivinen hahmo, joka toimii Rajalan omien mielipiteiden välittäjänä, 
kuten hän loppusanoissaan tunnustaa: "Hän [Fanny] valitsi itsensä ja oman tyylilajinsa. Kirjan tekijänä sain seurata hänen pulppuilevaa puhettaan, jonka olin elävänä kuulevinani. Turha minun oli häntä vastustaa, menkööt hänen tiliinsä omatkin aivoitukseni." Vaikka Fanny Davidson oli historiallinen hahmo, jota Erkko todella kosi, ei kertoja-Fanny ole dokumentaarinen aikalaistodistaja, kuten Rajala haluaa lukijalleen uskotella. Loppusanoissaan Rajala itsekin myöntää tämän: "Olisi houkuttelevaa vihjaista, että käsiini on tullut Fanny Sarton jälkeen jääneitä papereita, muistiinpanoja, Erkon elämäkerran katkelmia. Tyydyin kuitenkin kirjoittamaan ne itse."

Fiktiivisen kertojahahmon valinta ei sinänsä ole Runoilijan sydän -teoksen heikkous, mikäli teosta tarkastellaan romaanina, mielikuvituksen tuotteena, eikä tietokirjana, jonka tarkoitus olisi perustella väitteensä dokumentein. Parhaimmillaanhan aikalaistodistajan näkökulma voi elämäkerrallisessa romaanissa toimia kontekstia laventavana ja rehevöittävänä tekijänä tuoden esiin ajalle tyypillisiä arvoja ja moraalia. Tämä ei Rajalan teoksessa kuitenkaan toteudu.

Runoilijan sydän-teoksen ytimenä on selvittää runoilija J. H. Erkon seksuaalista suuntautumista. Tämä kilpistyy romaanin loppupuolelle rakennettuun kahteen pikkusievään kohtaukseen. Ensin kertojaminä pohdiskelee itse Erkon viehtymystä yhä nuorempiin naisiin ja päättelee tällä olleen pedofiilisiä taipumuksia. Pitkälle kertoja ei kuitenkaan arveluihinsa uskaltaudu ja siloittaa oitis mahdollisen kuprun kansallisrunoilijan kunniassa kääntämällä tämänkin taipumuksen runolliseksi muusaksi: "Kuinka raisusti hän sentään itse osasikaan oman luontumuksensa runoksi laatia ja sen kustannuksella vähän huvitellakin, tämä ikuinen nuorukainen, luonnonlapsen kaltainen.” Vielä myöhemmin Fanny kertoo käänteentekevästä kohtaamisestä erään Erkon Euroopan-matkan mielitietyn kanssa. Tämä paljastaa Erkon olleen homoseksuaali. Pienet tytöt kiehtoivat Erkon mieltä tämän mielestä, koska heidän kehonsa olivat poikamaisia, aikuisiin naisiin Erkko ei tuntenut vetoa.

Mikä elämäkerrallinen arvo on tällaisilla paljastuksilla teoksessa, jota markkinoidaan tietokirjana? Entä mikä on niiden historiallinen totuusarvo? Rajalan teos palauttaa mieleen taannoisen, samaan aikakauteen sijoittuneen Ven$n y$-televisiosarjan synnyttämän kiihkeän keskustelun tunteiden ja seksuaalisuuden historiallisuudesta, ilmaisutapojen ja moraalikoodistojen muutoksesta. Rajala kyllä koettaa osoittaa olevansa tietoinen historiallisesta etäisyydestä. Kun kertoja alkaa pohdiskella Minna Canthin eroottisuutta ja suhdetta Erkon veljeksiin, hän toteaa lopuksi: "Ounasteluni noutavat esikuvia oman aikani höltyneistä tavoista."

Mutta mistä "omasta ajasta" kertoja puhuu? Erkon kuollessa vuonna 1906 Fanny oli 29-vuotias. Hän kuoli itse kuusikymmentäluvun alussa. Kertoja vertaakin Erkon aktiivisen flammausajan "avioliittouskovaisia" tapoja omaan aikaansa, 
villiin 1900-lukuun, mikä jää vuosissadan alun kontekstia tuntevalle lukijalle vieraaksi ajatukseksi. Vaikka Fannyn kertomisen aika leviääkin 1900-luvun alkuvuosista kuusikymmenluvun alkupuolelle, voi tuskin olettaa kahdeksankymppisenkään Fannyn olleen tietoinen "ajan höltyneistä tavoista". Ennemmin teoksen punainen lanka, uteliaisuus Erkon seksuaalisuutta kohtaan, kielii oman aikamme arvoista ja moraalista. Tätä ei edes fiktiivisen kertojan käyttö Rajalan teoksessa peitä.

Minna Maijala 


\section{Edith Södergran och Rudolf Steiner}

Jan Häll: Vägen till landet som icke är. En essä om Edith Södergran och

Rudolf Steiner. Helsingfors/Stockholm: SLS/Atlantis 2006. 299 s.

Jan Häll konstaterar i inledningen till sin bok att samtidigt som Rudolf Steiners betydelse för Edith Södergran under hennes fyra sista levnadsår är ett erkänt faktum, har forskningens intresse för saken varit förvånansvärt lamt. Före Hälls bok har inga specialstudier ägnats denna fråga, inte ens i artikelform. Det är riktigt att det i stort sett bara är i Gunnar Tideströms grundläggande monografi från 1949 och Ernst Brunners avhandling Expressionisten Edith Södergran från 1985 som man finner utförligare resonemang om Steiners betydelse för Södergran. Häll förmodar - på ett lite självgratulerande sätt - att det svala intresset för relationen Södergran-Steiner främst beror på forskarnas ödmjukhet och bristande kompetens inför den esoteriska idévärld det rör sig om. Och Jan Häll, som disputerat på Swedenborg, är onekligen en lämplig person att ta sig an Steiners verk.

I sin beskrivning av forskningsläget förbigår Häll dock frågan om olika akademiska discipliner och kunskapsintressen. Hans egen forskningsansats beträffande Södergran och Steiner är av kombinerat person- och idéhistorisk art, inte litteraturvetenskaplig. Biografiskt inriktad Södergranforskning har efter Tideströms arbete stått lågt i kurs, och rent personhistorisk forskning utan ambitioner att på något sätt förklara diktningen har ju överhuvud inte på länge betraktats som en del av litteraturforskningen. Att denna inte tagit sig an Steiner mera än vad som varit fallet kan vid sidan av kompetensfrågor således bero på att man inte bedömt det som tillräckligt löftesrikt vad gäller nya perspektiv på Södergrans diktning.

Faktum är att inte heller Hälls undersökning för med sig några nämnvärda nya rön vad gäller förståelsen av Södergrans sena dikter. Först som sist rör sig resultaten på levnadsteckningens område. Dikterna kommenteras och analyseras knappt alls, vilket på ett mindre övertygande sätt motiveras med att "liv och dikt hos Södergran är så intimt sammanvävda att en ensidig och närsynt textanalys i längden blir missvisande". Snarast är det väl, för att travestera Häll själv, en fråga om kompetens, det vill säga en icke-litteraturvetares (alltför) ödmjuka hållning till en annan disciplins metoder.

Häll ger i varje fall en fin bild av Södergrans intellektuella och religiösa utveckling under perioden från hösten 1919 fram till hennes död midsommaren 1923 , med tonvikt på hur läsningen av Steiner tydligen banat en väg bort från Nietzsche och på så sätt indirekt öppnat vägen för en ny diktsyn, där intim naturkänsla är ett viktigt inslag. Södergrans lokala kontakter i Raivola med omgivning som haft betydelse för hennes Steinerintresse och hennes kristna orientering under de sista åren utreds fint, och Häll använder också 
källmaterial som tidigare forskning förbigått.

Häll beskriver skickligt, utan att förlora sig i detaljer, de delar av Steiners tänkande som man kan anta att Södergran bekantat sig med, och som tidvis också präglade hennes vardag $\mathrm{i}$ form av ett antal "andliga övningar" som enligt Steiners anvisningar skulle leda till herravälde över tanke, känsla och vilja. Därtill kommer naturkontemplation som hänger samman med den immanenta art av mystik man finner hos Steiner. Sinnevärlden är inte avskild från den andliga världen, och det gäller att lära sig se mera, det vill säga se den andliga utsträckningen av den värld som omger människan.

Ett av huvudkapitlen i boken är "Vägen till Kristus", där Häll tämligen övertygande argumenterar för att den motsättning som man ofta velat se mellan Södergrans Steinerengagemang och hennes dragning till kristendomen är konstgjord: Steiners tänkande har ju en kristen bas, och Steiners skrifter är därmed i sig en väg till kristendomen. $\AA$ andra sidan medger Häll att det finns en viss spänning mellan Steiners väg och den evangeliska, i bibelläsning förankrade kristendom som Södergran kom nära bland annat genom kontakten med en lokalt verksam diakonissa.

Sin metod betecknar Häll lite kryptiskt som "topografisk", vilket väl får tolkas så att han ser sitt grepp som kartläggande och beskrivande snarare än djupgående analytiskt. Det viktigaste materialet för undersökningen består, förutom ett ur- val av Steiners produktion, av Södergrans brevväxling särskilt med Hagar Olsson. Breven till Olsson och Olssons kommentarer till breven är ju synnerligen välkända, varför nyhetsvärdet i vissa partier av Hälls bok är lågt. Det kan dock motiveras med att det är fråga om en essäistisk framställning som tar sikte på en bredare läsekrets, vilket nog ger rum för läsarvänlighet i form av ganska utförliga citat och referat också av kända texter. Det essäistiska greppet har inte hindrat att boken försetts med detaljerad referensapparat, vilket är utmärkt. När det gäller tidigare forskning är dock hänvisningarna irriterande oprecisa. Det finns åtskilliga vaga hänvisningar till "Södergranforskningen" och "Södergranlitteraturen", och formuleringar av typen "Man har menat att ..." och "... som man i Södergranlitteraturen på ett fatalt sätt missbedömt". Vem Häll har i tankarna och precis vad han bekantat sig med i den tidigare forskningen förblir oklart.

I det avslutande kapitlet går Häll äntligen in på frågan om Steiners betydelse för dikterna. Kanske en aning överraskande blir kontentan i det stora hela att Steinerläsningen inte har haft någon nämnvärd betydelse för Södergrans sena dikter och aforismer, däribland "Min barndoms träd", "Hemkomst" och "Tankar om naturen" - beröringsytorna mellan Steiner och diktningen är alltför vaga och allmänna. Steiners betydelse ligger i att han hjälpt Södergran att befria sig från den tidigare diktsynen, men någon direkt andel i det nya kan han inte sägas ha. 
Poesi är inte filosofi, och Södergrans sista dikter har förvisso sin viktigaste grogrund i annat än läsande. På ett sympatiskt och klokt sätt aktar sig alltså Häll i slutkapitlet för att med våld läsa in frukterna av sin Steinerforskning i Södergrans dikter: "Det måste ... sägas generellt om den nya diktningen att den i huvudsak inte låter sig läsas som någon sorts lyrisk transponering av innehållet i Steiners böcker och föredrag - den är långt mer än så”. Å andra sidan måste det sägas att avsaknaden av diktanalyser gör att man efter avslutad läsning inte upplever att frågan om Steiner och dikten fått en helt tillfredsställande behandling. Häll gör det lite väl enkelt för sig genom att undvika en utförligare diskussion om de sena dikternas natur- och gudsuppfattningar och frågan hur dessa står i förhållande till Steiner.

\section{Holger Lillqvist}




\section{Kuulumisia Espanjan Mannerilta}

Tuula Hökkä (toim.): Kirjoittamisen aika. Eeva-Liisa Mannerin kirjeitä 1963-1969. Helsinki: Tammi 2006. 415 s.

Eeva-Liisa Mannerin kirjeitä on jännittävää lukea. Tulee houkutus vertailla kirjeitä kirjailijan teoksiin, mutta syntyy myös halu lukea kirjeitä Mannerin omina sanoina, ikään kuin kirjailija itse puhuisi tässä ja nyt. Jatkuvasti on kysyttävä, onko kirjeiden tekijä sama kuin runojen, näytelmien, suomennosten ja lukuisten muiden kirjallisten töiden tekijä? Vai onko jokaisella teoksella ja jokaisella kirjeelläkin oma tekijänsä? Nämä houkutukset ja kysymykset muodostavat yhden Tuula Hökän toimittaman Mannerin kirjekokoelman kiehtovimmista teemoista. Manner itse pohti kirjeissään usein itseen ja kirjoittamiseen liittyviä kysymyksiä. Myös Hökkä reflektoi kirjeiden tekijyyden motiivia ja motivaatioita teokseen laatimassaan kiinnostavassa esipuheessa: "Itsereflektio on loputon kirjoittamisen metodi ja ponnin. Itse on kirjailijan kulumaton perusaihe." (s. 14)

Mannerin ääni on Kirjoittamisen aika -teoksessa vahva, kuten teoksen toimittaja on omien sanojensa mukaan tarkoittanutkin. Teokseen on koottu pääasiassa Mannerin kirjoittamia kirjeitä ja kortteja äidinkielen yliopettaja Anna-Liisa Mäenpäälle, kirjailija-psykiatri Oscar Parlandille sekä tämän Heidi-vaimolle, nykytaiteen keräilijä Sara Hildénille ja kirjailija Inkeri Kilpiselle. Mukana on myös hä- nelle osoitettuja vastauksia ja muita yhteydenottoja. Viestinvaihtoa on lisäksi monien muiden kulttuurivaikuttajien kanssa. Hökkä onnistuu pitämään henkilögallerian, keskustelujen kulun sekä lukijankin otteessaan huolellisten selitysten avulla. Jokaisesta kirjeessä esiintyneestä henkilöstä mainitaan ainakin koko nimi ja ammatti, ja viitatuista tapahtumista ja projekteista annetaan kirjeenvaihdon seuraamista helpottavat, usein kattavatkin kuvaukset.

Hökkä perustelee kirjeiden ajallista rajausta vuosiin 1963-1969 sillä, että nämä vuodet ovat Mannerin tuotteliainta aikaa. Mannerin kirjeissään tekemät lukuisat viittaukset kullakin hetkellä keskeneräisiin töihin, etenkin proosa- ja draamakäännöksiin, todistavat kauden hektisyydestä. Kirjoittamisen aikaa lukiessa myös Mannerin runo- ja draamateokset ovat koko ajan ainakin kirjeiden aiheina läsnä. Tuula Hökkä ei ole pyrkinyt häivyttämään teosten ja kirjeiden kytköstä, päinvastoin. Hän tuo usein esille Mannerin kirjeissään mainitsemien konkreettisten tapahtumien ja ideoiden yhteydet tekeillä oleviin tai jo julkaistuihin teoksiin. Jäin miettimään näiden yhteyksien tarkoitusta. Kun Mannerin tuotantoa kytketään hänen kokemuksiinsa ja ajatuksiinsa, Mannerin kirjailijuudesta muodostuu lukijalle moniulotteisempi ja täydempi kuva. Toisaalta lukija voi myös kysyä, tarjotaanko hänelle jonkinlaista lukuohjetta Mannerin tuotantoon.

Mannerin runoteoksille keskeiset paikan ja paikallisuuden kokemisen teemat toistuvat ja limittyvät kiinnostavasti 
Hökän alkusanoissa ja Mannerin kirjeissä. Hökkä kuvailee alkusanoissaan elävästi Andalusian maisemia, ja rinnastaa Churrianan kylän Mannerin kaipaamaan Viipuriin. Piskuinen Churrianan kylä hallitsee myös Mannerin kirjeitä, mutta erityisesti Mannerin asumat talot, ensin Sara Hildénin omistama taiteilijatalo Villa Pastora ja sitten Mannerin itselleen ostama Elmirador, sekä myös Mannerin Mäenpäälle myymä Havisevan kesäasunto elävät kirjailijan rinnalla tietynlaisina kirjeiden päähenkilöinä. Manner kirjoittaa toistuvasti Hildénille Villa Pastoran rappeutumisesta ja pyytää häntä tulemaan Churrianaan vuoroin itsensä ja vuoroin talon vuoksi - rivien välistä voi lukea, että sekä talo että kirjailija Manner kaipaavat kipeästi Saran huomiota ja ystävyyttä!

Ystävyys on tekijyyden, itsen ja niiden suhteiden reflektoimisen lisäksi toinen Kirjoittamisen ajan kantava teema. Mäenpään ja Mannerin kirjeenvaihtoa voi lukea ystävyyden jännitystarinana, jolla on hitaasti lämpenevän alun ja myrskyisiksikin yltyneiden juonenkulkujen jälkeen oudosti hiipuva loppu. Mannerin ja Mäenpään kirjeet asettuvat kiinnostavaan vuoropuheluun kiihkeän ystävyystarinan kanssa, jonka Helena Sinervo kirjoittaa vuonna 2004 julkaistussa Runoilijan talossa -elämäkertaromaanissa. Kirjoittamisen ajan kirjeiden tarinallistuminen ja niiden kirjoittajien ja vastaanottajien muuntuminen rooleiksi tulee esille toimittajan esipuheessa. Hökkä kiinnittää esipuheessaan lukijan huomion myös kirjeiden tehtävään eli siihen, että ne on kirjoitettu tietylle vastaanottajalle tietyssä tarkoituksessa. Hökän mukaan tämä kirjeiden tehtävä on valjastettavissa myös kirjallisuudentutkimuksen tarkoituksiin. Hökkä ei tarkenna ajatustaan, mikä jääkin mietityttämään, ehkä myös inspiroimaan kirjallisuudenopiskelijan ja -tutkijan mieltä.

\section{Karoliina Lummaa}




\section{Fanikohtaisia luentoja rock-sanoituksista}

Toni Lahtinen ja Markku Lehtimäki (toim.): Ä̈̈niä äänien takaa. Tulkintoja rock-lyriikasta. Tampere: Tampere University Press 2006. 309 s.

Saahan se tanssimaan, mutta onko se taidetta? Kysymystä rock-musiikin taiteellisesta merkityksestä on pyöritelty useammin kulttuurintutkijoiden ja sosiologien leireissä kuin kirjallisuustieteessä. Tampereen yliopistossa syksyllä 2004 järjestetty rock-lyriikan seminaari todisti kuitenkin, että vakavaa kiinnostusta rokkenrolliin löytyy myös sanataiteen tutkijoilta. Seminaarin pohjalta pakerrettu artikkelikokoelma Ä̈̈niä äänien takaa todistaa vähintäänkin tutkimuskentän moninaisuuden.

Rock-lyriikka toimii yhtä hyvin minioopperan muotokeinoilla kuin shokkiefektiksi tarkoitetuilla sanoituksilla. Lajin laveus ilmenee vaikkapa siinä, kuinka paljon jo kotimaisen kentän kartoitus vaatisi lyriikan perinteisten muotojen tuntemusta. Kartoituksen pitäisi pystyä sisällyttämään kaikki kaunis Martti Syrjän riimittelystä Kari Peitsamon nonsenseen, Juice Leskisen soneteista A.W. Yrjänän uusromantiikkaan.

Toni Lahtisen ja Markku Lehtimäen toimittamassa kokoelmassa osansa saavat ne artistit, joille on löytynyt ilmeisen fanikohtainen tutkijansa. Suomalaisista esiintyjistä mukana ovat vain rovaniemeläinen rap-ryhmä Tulenkantajat sekä helsinkiläinen, rockin miestähteyttä iro- nisoinut Gösta Sundqvist.

Painotus on vahvasti rockin eikä lyriikan puolella. Rock-kappaleita käsitellään kontekstipainotteisesti, laulujen merkitystä ajankohtansa ja fanikuntansa oloisena kommunikaationa. Välillä mennään popin ja iskelmän puolelle, mutta kohde tunnistetaan ja arvotetaan rockiksi oikeasta asenteesta. Lähtökohtaisesti kyse ei ole sen kummemmasta kuin lauletun ja luettavan lyriikan eroista eli siitä, "minkälaisia merkityksiä äänellinen tulkinta tuo kirjoitetun lyriikan ilmimerkityksiin”, kuten toimittajat toteavat. Kuitenkaan rock-lyriikan sisällöistä, saati musiikillisista muodoista, ei saisi täyttä käsitystä ilman musiikkilajin taustatietämystä. Vasta lajikonteksti antaa kliseillekin lisäarvoa. Tämän kokoelma osaltaan todistaa.

Sävellysten sijaan artikkelit hakevat taustoja tarkkaan rajatuista sisällöllisistä interteksteistä. Poikkeuksena on Anne Tarvaisen artikkeli, jossa Björkin "Sun in my mouth" avataan painotusten, alleviivausten ja sisäisten viittausten artikulaationa. Tarvaisen artikkeli onkin ainoa sellainen luenta, joka täyttää kirjan toimittajien lupauksen selvittää lauletun ja luettavan lyriikan eroja. Kaikki muut artikkelit ovat intertekstuaaliselle tutkimukselle ominaisia parafraasiketjuja laulujen kulttuurisesta lastista. Kootut sitaattiselitykset kiinnostavat ja koskettavat lähinnä artistien faneja. Kirjallisuudentutkimuksen kannalta kokoelman anti on vähäpätöinen.

Tähtikohtaisiin tulkintoihin päästään intertekstienkin kautta. Tulkintojen pätevyys perustuu sille, kuinka tunnetulle ar- 
tistille osoitetaan jokin erityinen yllättävä konteksti. Rockin tähtikultin merkittävyyden kiteyttää toimittaja Antti Nylén artikkelissaan fetissiksi muuttuneesta äänestä: "popissa varsinainen teos on itse tekijä."

Toisaalta näyttää vakavasti siltä, että rock-lyriikan tunnusominaisin piirre olisi ironia. Tämä ei ole kirjoittajien valitsema näkökulma, mutta heidän tulkintojaan selvästi yhdistää ajatus artistista, joka erottuu muusta rockmusiikista pilkkaamalla omaa tähteyttään (Morrisey, Tori Amos, Gösta Sundqvist, Tulenkantajat) tai sanoitusten viihdyttävyyttä ja sanomallisuutta (Lennon, Eminem).

Ironian monikerroksisuudesta käy hyväksi esimerkiksi John Lennonin tapa käyttää ristiriitaisia alluusioita tulkitsijoidensa kiusaamiseksi. Jussi Willmanin syväluotaus Lennonin sanoitusten monikerroksisuudesta onkin kokoelman popoppinein luenta. Willman osoittaa, että kirjallisuuden asiantuntija voi pahasti aliarvioida tulkitsemansa tekstin, esimerkiksi käännöksen yhteydessä, kuten Pentti Saarikoski suomentaessaan Lennonin runoutta, mikäli hän ei tunne osakulttuurin sisällä käytyä dialogia ja tähtikulttia.

Osuvampi nimi tälle artikkelikokoelmalle olisikin Tulkintoja rock-tähteydestä, niin keskeisessä asemassa on artistin rakentama paikka rock-kulttuurin sisällä. Perinteisempää rock-tähteyttä edustavat ne artistit, jotka ovat saavuttaneet myyttisen aseman. Heitä edustavat kokoelmassa Bruce Springsteen ja Jim Morrison. Springsteenin saavutettua asemansa suu- rena amerikkalaisena äänenä hänen tuotantoaan voi tarkastella koko americanan työstäjänä, kuten professori Bo Pettersson tekee artikkelissaan. Springsteenin sanoitusten puheenomainen vaikuttavuus ja yksinkertaisuus perustuu kertojaminän käyttämiin puhuttelumuotoihin, arvelee Pettersson. Sen syvällisempää tietoa ei Springsteenin lyriikasta irtoa.

Jim Morrisonin intensiivistä tuotantoa on valittu edustamaan klassikkokappale "The End?". Kappale on Morrisonin omin sanoin "riittävän kompleksinen ja kuvastoltaan universaali". Tämä lienee kelpo määritelmä mille tahansa intertekstuaalisuudessaan rikkaalle klassikolle, mutta Markku Lehtimäki esittää artikkelissaan myös kriteereitä näiden intertekstien rajaamiselle tutkimuksessa. Vaikka rock-kulttuuri on imenyt romanttisia aineksia monenlaisista vastakulttuureista, kannattaa Morrisonin ymmärtämiseksi etsiä kytköksiä erityisesti 1950-60-lukujen beat-runoudesta. Klassinen eurooppalainen lyriikka on kuitenkin ollut usein se vertailukohde, jonka avulla lyriikantutkijat ovat mieluusti todistelleet rocksanoitusten korkeatasoisuutta. Lehtimäki onnistuu selittämään paitsi Morrisonin sanoitusten myös ylipäänsä rock-lyriikan laulullisuutta niillä vaikutteilla, joita rock on imenyt amerikkalaisen vastakulttuurin varhaisvaiheessa.

Osakulttuurina rock on yhtä nuorta kuin kokoelman toimittajat, mutta sen asenne kantaa kaukaisiakin kaikuja kaupunkilaiselämän historiasta. Vaikka tutkitut artistit edustavat vaihtelevia rock- ja 
pop-musiikin lajeja, yhdistää heitä kaupunkilainen elämänkokemus ja -ahdistus. Rock-sanoitusten kapinallisuus perustuukin usein urbaanin elämän aggressiivisuuteen. Esimerkiksi Nine Inch Nailsin kauhukuvat tunnottomiksi muuttuneista ihmiskehoista juontavat juurensa yhtä hyvin aikamme populaarikulttuuriin kuin ranskalaiseen dekadenssiin. Niinpä Antti Nylén kirjoittaa Morrisseystä masokistisena dandyna ja Katja Laitinen Tori Amosista naisrockin kapinallisena, joka saattaa mytologisoida jopa oman raiskauksensa.

Rock-lyriikan poeettinen ominaisluonne jää tutkijoidenkin jäljiltä hämäräksi, mutta aihepiirinsä ensimmäisenä julkaisuna Ä̈niä äänien takaa varmasti innostaa nuoren polven tutkijoita. Sen, että kirja on koottu tamperelaisin voimin ja tulee tamperelaiselta kustantamolta, tulkitsen mieluusti "manserockin" asenteelliseksi perinnöksi. Tulihan myös sarjakuva akateemisesti hovikelpoiseksi juuri Tampereella.

\section{Markku Soikkeli}

